\title{
NMDA AND NON-NMDA GLUTAMATE RECEPTORS IN THE PARAVENTRICULAR NUCLEUS OF THE HYPOTHALAMUS MODULATE DIFFERENT STAGES OF HEMORRHAGE-EVOKED CARDIOVASCULAR RESPONSES IN RATS
}

\author{
C. BUSNARDO, ${ }^{a *}$ C. C. CRESTANI, ${ }^{b}$ A. FASSINI, ${ }^{a}$ \\ L. B. M. RESSTEL ${ }^{a}$ AND F. M. A. CORRÊA ${ }^{a}$ \\ ${ }^{a}$ Department of Pharmacology, School of Medicine of Ribeirão \\ Preto, University of São Paulo, Ribeirão Preto, São Paulo, Brazil \\ ${ }^{\mathrm{b}}$ School of Pharmaceutical Sciences, Univ. Estadual Paulista- \\ UNESP, Araraquara, SP, Brazil
}

\begin{abstract}
Here we report the involvement of $N$-Methyl-DAspartate (NMDA) and non-NMDA glutamate receptors from the paraventricular nucleus of the hypothalamus (PVN) in the mediation of cardiovascular changes observed during hemorrhage and post-bleeding periods. In addition, the present study provides further evidence of the involvement of circulating vasopressin and cardiac sympathetic activity in cardiovascular responses to hemorrhage. Systemic treatment with the $\mathrm{V}_{1}$-vasopressin receptor antagonist dTyr $\left(\mathrm{CH}_{2}\right)_{5}(\mathrm{Me}) A V P(50 \mu \mathrm{g} / \mathrm{kg}$, i.v.) increased the latency to the onset of hypotension during hemorrhage and slowed postbleeding recovery of blood pressure. Systemic treatment with the $\beta_{1}$-adrenergic receptor antagonist atenolol $(1 \mathrm{mg} /$ $\mathrm{kg}$, i.v.) also increased the latency to the onset of hypotension during hemorrhage. Moreover, atenolol reversed the hemorrhage-induced tachycardia into bradycardia. Bilateral microinjection of the selective NMDA glutamate receptor antagonist LY235959 (2 nmol/100 $\mathrm{nL})$ into the PVN blocked the hypotensive response to hemorrhage and reduced the tachycardia during the post-hemorrhage period. Systemic treatment with dTyr $\left(\mathrm{CH}_{2}\right)_{5}(\mathrm{Me}) \mathrm{AVP}$ inhibited the effect of LY235959 on hemorrhage-induced hypotension, without affecting the post-bleeding tachycardia. PVN treatment with the selective non-NMDA receptor antagonist NBQX $(2 \mathrm{nmol} / 100 \mathrm{~nL})$ reduced the recovery of blood pressure to normal levels in the post-bleeding phase and reduced hemorrhage-induced tachycardia. Combined blockade of both NMDA and non-NMDA glutamate receptors in the PVN completely abolished the hypotensive response in the hemorrhage period and reduced the tachycardiac response in the post-hemorrhage period. These results indicate that
\end{abstract}

\footnotetext{
*Corresponding author. Address: Department of Pharmacology, School of Medicine of Ribeirão Preto, USP, Ave. Bandeirantes, 3900, 14049-900 Ribeirão Preto, São Paulo, Brazil. Tel: +55-(16)3602-3206; fax: + 55-(16)-3633-2301.

E-mail address: crisbus@usp.br (C. Busnardo).

Abbreviations: ACF, artificial cerebrospinal fluid; ACTH, adrenocorticotropin; AVP, vasopressin; CMM, caudal midline medulla; HR, heart rate; MAP, mean arterial pressure; NMDA, $N$ Methyl-D-Aspartate; NTS, nucleus tractus solitarius; PAP, pulsatile arterial pressure; PVN, paraventricular nucleus of the hypothalamus; RVLM, rostral ventrolateral medulla; vIPAG, ventrolateral column of the periaqueductal gray.
}

local PVN glutamate neurotransmission is involved in the neural pathway mediating cardiovascular responses to hemorrhage, via an integrated control involving autonomic nervous system activity and vasopressin release into the circulation. (c) 2016 IBRO. Published by Elsevier Ltd. All rights reserved.

Key words: cardiovascular system, glutamate neurotransmission, hemorrhagic shock, paraventricular nucleus of hypothalamus, sympathetic activity, vasopressin.

\section{INTRODUCTION}

Hemorrhagic shock is a serious complication that may occur as a result of trauma, surgery, gastrointestinal disease, and anticoagulant therapy (Levi et al., 2002; Siqueira and Schmidt, 2003; Gutierrez et al., 2004). Tissue perfusion is reduced during hemorrhagic shock, due to a loss of circulating blood volume (Garrioch, 2004), which can lead to death. Indeed, hemorrhage is implicated in millions of deaths worldwide (Levi et al., 2002; Siqueira and Schmidt, 2003; Gutierrez et al., 2004), and is the leading cause of trauma-associated deaths (Bellamy, 1984; Abjean, 1986; Moore et al., 1996; Cuschieri et al., 2012; Malinoski et al., 2012). Early emergency care and treatment for severe trauma are extremely important, because about $40 \%$ of trauma-induced deaths occur 5-30 min after trauma (Cherkas, 2011; Liu et al., 2013).

Blood loss triggers a complex set of neural and hormonal responses intended to preserve blood flow to vital organs and to reduce tissue energy consumption (Garrioch, 2004). These responses are triggered by arterial baroreceptors and atrial volume receptors, which transmit information about changes in blood volume and pressure to the nucleus tractus solitarius (NTS) (Loewy, 1990; Jaworski and Blair, 2004). These sensory signals are transmitted to supramedullary structures through ascending projections that originate in the NTS and ventrolateral regions of the medulla (Loewy, 1990). However, the central organization of neural networks responsible for the nervous and hormonal regulation of blood pressure during hemorrhage remains unclear.

The paraventricular nucleus of the hypothalamus (PVN) is comprised of magnocellular neurosecretory 
neurons as well as preautonomic and neuroendocrine parvocellular neurons (Swanson and Kuypers, 1980). The preautonomic parvocellular region of the PVN contains neurons projecting directly to the intermediolateral cell column of the thoracolumbar spinal cord and the rostral ventrolateral medulla (RVLM), which constitute important regions involved in the regulation and generation of sympathetic activity (Kuypers and Maisky, 1975; Shafton et al., 1998; Pyner et al., 2001). Magnocellular neurons synthesize the neurohypophysial hormones oxytocin and vasopressin, which are axonally transported down to the neurohypophysis and subsequently secreted into the bloodstream (Bisset and Chowdrey, 1988). Labor and milk ejection involve an oxytocin release, whereas vasopressin is released in response to decreased blood pressure or blood volume and increased plasma osmolality (Cunningham and Sawchenko, 1991; Renaud and Bourque, 1991; Cunningham et al., 2002, 2004).

It has been reported that hemorrhage causes a massive activation of both magnocellular neurosecretory and parvocellular neurons in the PVN (Roberts et al., 1993; Li and Dampney, 1994; Petrov et al., 1995; Badoer, 1996; Badoer and Merolli, 1998; Krukoff, 1999). Accordingly, previous studies reported an involvement of the PVN in the elevation of circulating corticosterone and adrenocorticotropin (ACTH) induced by hemorrhagic stimuli (Darlington et al., 1988; Blair et al., 1998). However, the possible role of this hypothalamic nucleus in the control of cardiovascular function during hemorrhage is poorly understood (Darlington et al., 1988; Blair et al., 1998).

We have previously reported that glutamate neurotransmission is an important local signaling mechanism in the PVN, being involved in the regulation of cardiovascular function (Busnardo et al., 2009, 2013). We observed that PVN stimulation with L-glutamate (L-glu) caused pressor and tachycardiac responses that were mediated by activation of $N$-Methyl-D-Aspartate (NMDA) glutamate receptors and subsequent sympathetic stimulation. When NMDA receptors were blocked, the microinjection of L-glu into the PVN caused pressor and bradycardiac responses that were mediated by activation of local non-NMDA glutamate receptors with a vasopressin release into the circulation (Busnardo et al., 2009). Therefore, the control exerted by PVN glutamate neurotransmission on the cardiovascular system is mediated by both neural (sympathetic) and humoral (vasopressin) factors. Nevertheless, to the best of our knowledge, the involvement of PVN glutamate neurotransmission in the control of cardiovascular responses evoked by hemorrhagic stimuli has never been evaluated. Thus, our hypothesis is that glutamate neurotransmission in the PVN modulates the cardiovascular system during hemorrhage by integrating sympathetic and vasopressin mechanisms.

\section{EXPERIMENTAL PROCEDURES}

\section{Subjects}

Experimental procedures were carried out following protocols approved by the Ethical Review Committee of the School of Medicine of Ribeirão Preto (Protocol number 075/2015), which comply with requirements established by the National Institutes of Health (NIH). Male Wistar rats weighing approximately $250 \mathrm{~g}$ were used in the present experiment. Animals were housed in plastic cages in a temperature-controlled room $\left(25^{\circ} \mathrm{C}\right)$ in the Animal Care Unit of the Department of Pharmacology, School of Medicine of Ribeirão Preto. Animals were kept under a 12:12-h light-dark cycle (lights on between 06:00 and 18:00 h). Animals had free access to water and standard laboratory food, except during the experimental period.

\section{Surgical preparation}

To implant guide cannulas bilaterally in the PVN, five days before the trial, the animals were anesthetized with tribromoethanol $(250 \mathrm{mg} / \mathrm{kg}$, i.p.) and their heads fixed to a stereotaxic apparatus (Stoelting, Wood Dale, IL, USA). The skull was surgically exposed and trepanned with a dental drill at $1.9 \mathrm{~mm}$ from the medial line and $7.2 \mathrm{~mm}$ anterior to the interaural line (Paxinos and Watson, 1986). Bilateral stainless steel guide cannulas (24G, $13 \mathrm{~mm}$-long) were lowered $8 \mathrm{~mm}$ from the skull, at a $12^{\circ}$ angle to both sides. Guide cannulas were positioned $1 \mathrm{~mm}$ above the intended stimulation sites, and fixed to the skull with a metal screw and dental cement. After surgery, the animals received a poly-antibiotic formulation with streptomycins and penicillins to prevent infection (80.000 UI, i.m.) and the nonsteroidal antiinflammatory flunixine meglumine for post operation analgesia $(2.5 \mathrm{mg} / \mathrm{kg}$, s.c.).

Twenty-four hours before the experiment, animals were anesthetized with tribromoethanol $(250 \mathrm{mg} / \mathrm{kg}$, i.p.) and polyethylene catheters were implanted into the right femoral artery for cardiovascular recording and into the left femoral artery for blood withdrawal (hemorrhage) and drug injection when it was necessary. The catheters were exposed on the dorsum of the animals and attached to the skin, allowing cardiovascular recording and blood withdrawal of unanesthetized rats in their own cage. Flunixine meglumine $(2.5 \mathrm{mg} / \mathrm{kg} \mathrm{s.c.}$ ) was used for post operation analgesia.

\section{Cardiovascular recording}

The catheter was connected to a pressure transducer and pulsatile arterial pressure (PAP) was recorded using a HP-7754A pre-amplifier (Hewlett Packard, Palo Alto, CA, USA) and an acquisition board (MP100A, Biopac Systems Inc., Goleta, Santa Barbara, CA, USA) connected to a personal computer. Mean arterial pressure (MAP) and heart rate $(H R)$ values were derived from PAP recordings using the Acknowledge III software (Biopac, USA). MAP was calculated according to the equation: diastolic pressure + (systolic - diastolic)/3. HR (bpm) was calculated from PAP peak intervals integrated every $6 \mathrm{~s}$.

\section{Hemorrhage}

All animals underwent a fixed volume hemorrhage of $24 \mathrm{~mL} / \mathrm{kg}$ (estimated as $30 \%$ of total blood volume) over 
a period of $20 \mathrm{~min}(1.2 \mathrm{~mL} / \mathrm{min} / \mathrm{kg})$. This rate evokes clear periods of compensation, decompensation, and recompensation (Troy et al., 2003). Blood was withdrawn via the left femoral artery using a withdrawal pump (K.D. Scientific, Holliston, MA, USA). MAP and HR were recorded for a further 40-min period after the completion of hemorrhage.

\section{Drugs and solutions}

LY235959 ([3S-(3a,4aa,6b,8aa)]-Decahydro-6-(phospho nomethyl)-3-is oquinolinecarboxylic acid) (TOCRIS, Westwoods Business, Park Ellisville, MO, USA) and NBQX (2,3-dioxo-6-nitro-1,2,3,4-tetrahydrobenzo[f]qui noxaline-7-sulfonamide) (TOCRIS) were dissolved in artificial cerebrospinal fluid (ACF), which had the following composition: $\mathrm{NaCl} 100 \mathrm{mM}, \mathrm{Na}_{3} \mathrm{PO}_{4} 2 \mathrm{mM}$, $\mathrm{KCl} 2.5 \mathrm{mM}, \mathrm{MgCl}_{2} 1.0 \mathrm{mM}, \mathrm{NaHCO}_{3} 27 \mathrm{mM}, \mathrm{CaCl}_{2}$ $2.5 \mathrm{mM}, \quad \mathrm{pH}$ 7.4. DTyr $\left(\mathrm{CH}_{2}\right)_{5}(\mathrm{Me}) \mathrm{AVP}$ (Peninsula, Belmont, CA, USA), atenolol (SIGMA, St. Louis, MO, USA), tribomoethanol (SIGMA) and urethane (SIGMA) were dissolved in saline $(\mathrm{NaCl} 0.9 \%)$. Flunixine meglumine (Banamine $\AA$, Schering Plough, RJ, Brazil) and the poly-antibiotic preparation of streptomycins and penicillins (Pentabiotico ${ }^{\circledR}$, Fort Dodge, SP, Brazil) were used as provided.

\section{Drug microinjection into the PVN}

The needles (33 gauge; Small Parts, Miami Lakes, FL, USA) used for microinjection of drugs into the PVN were $1 \mathrm{~mm}$ longer than the guide cannulas. The injection needles were connected to a $1-\mu \mathrm{L}$ syringe $(7001 \mathrm{KH}$; Hamilton, Reno, NV, USA) through PE-10 tubing and bolus injections of $100 \mathrm{~nL}$ were made into the PVN (Busnardo et al., 2007, 2009; Crestani et al., 2009). Microinjections were performed within a 5-s period. After microinjection, the needle was left within the guide cannula for $1 \mathrm{~min}$ before being removed. Drugs were prepared before the experiments and stored at $-20^{\circ} \mathrm{C}$. On the day of the experiment, the drugs were thawed and kept at $0^{\circ} \mathrm{C}$ during experiments.

\section{Experimental procedure: hemorrhage}

Rats were transported to the experiment room in their own cages and were allowed at least $60 \mathrm{~min}$ to adapt to the experimental room conditions, such as sound and illumination, before starting the experiments. Cardiovascular recording began at least 30 min before hemorrhage onset and was continuously performed during the 20-min period of hemorrhage up to $40 \mathrm{~min}$ after the completion of hemorrhage. All pharmacological treatments (see below) were performed $10 \mathrm{~min}$ before hemorrhage onset. Experiments were performed during the morning period in order to minimize possible circadian rhythm interferences.

Effect of systemic treatment with $\operatorname{dTy}\left(\mathrm{CH}_{2}\right)_{5}(\mathrm{Me}) \mathrm{AVP}$ or atenolol on the cardiovascular responses to hemorrhage in unanesthetized rats. This protocol aimed to investigate the role of circulating vasopressin and cardiac sympathetic activity in cardiovascular responses to hemorrhage in unanesthetized rats. For this, an independent set of animals was treated intravenously with either saline (control, $1 \mathrm{~mL} / \mathrm{kg}$ ), the selective $\mathrm{V}_{1}$-vasopressinergic receptor antagonist dTyr $\left(\mathrm{CH}_{2}\right)_{5}(\mathrm{Me})$ AVP $(50 \mu \mathrm{g} / \mathrm{mL} / \mathrm{kg})$ (Busnardo et al., 2009), or the selective $\beta_{1}$-adrenoceptor antagonist atenolol $(1 \mathrm{mg} / \mathrm{mL} / \mathrm{kg})$ (Dos Reis et al., 2014).

Effect of PVN treatment with LY235959, NBQX, or the combination of LY235959 + NBQX on the cardiovascular responses to hemorrhage in unanesthetized rats. This protocol aimed to investigate the involvement of glutamate neurotransmission in the PVN in cardiovascular changes induced by hemorrhage. For this, animals were divided into four experimental groups: (1) ACF, in which the vehicle ACF $(100 \mathrm{~nL})$ was microinjected bilaterally into the PVN; (2) NBQX, in which the selective non-NMDA glutamate receptor antagonist NBQX (2 nmol/100 nL) was microinjected bilaterally into the PVN; (3) LY235959, in which the selective NMDA glutamate receptor antagonist $(2 \mathrm{nmol} / 100 \mathrm{~nL})$ was microinjected bilaterally into the PVN; and (4) LY235959 + NBQX, in which a combined microinjection of LY235959 (2 nmol/100 nL) and NBQX $(2 \mathrm{nmol} / 100 \mathrm{~nL})$ was made bilaterally into the PVN (Busnardo et al., 2009, 2013).

Effect of PVN treatment with LY235959 in animals treated systemically with dTyr $\left(\mathrm{CH}_{2}\right)_{5}(\mathrm{Me})$ AVP on cardiovascular responses to hemorrhage in unanesthetized rats. This protocol aimed to investigate the involvement of circulating vasopressin in the modulation of cardiovascular responses to hemorrhage involving NMDA glutamate receptors in the PVN. For this, animals were subjected to combined treatment with dTyr $\left(\mathrm{CH}_{2}\right)_{5}(\mathrm{Me})$ AVP $(50 \mu \mathrm{g} / \mathrm{mL} / \mathrm{kg})$ into the left femoral artery and LY235959 (2 nmol/100 $\mathrm{nL})$ bilaterally into the PVN.

\section{Histological determination of the microinjection sites}

At the end of experiments, animals were anesthetized with urethane $(1.25 \mathrm{~g} / \mathrm{kg}$, i.p.) and $100 \mathrm{~nL}$ of $1 \%$ Evan's blue dye was injected into the brain as a marker of the injection site. They were then submitted to intracardiac perfusion with $0.9 \% \mathrm{NaCl}$ followed by $10 \%$ formalin. Brains were removed and postfixed for $48 \mathrm{~h}$ at $4^{\circ} \mathrm{C}$. Then, serial $40-\mu \mathrm{m}$-thick sections were cut with a cryostat (CM1900, Leica, Wetzlar, Germany). Sections were treated with propylene glycol and stained with $4 \%$ cresyl violet for light microscopy analysis. The actual placement of the microinjection needles was determined by analyzing serial sections and identified according to the rat brain atlas of Paxinos and Watson (Paxinos and Watson, 1986). Data from animals for which microinjection sites were located in regions surrounding the PVN were excluded from the study. 


\section{Statistics}

Data were expressed as mean \pm SEM. Basal values of MAP and HR before and after pharmacological treatments were compared using the Student's paired $t$ test. The time-course curves of MAP and HR changes were analyzed using a two-way ANOVA, with treatment as the main independent factor and time as the repeated measurement. When interaction between factors was observed, groups were compared using a one-way ANOVA followed by Bonferroni's post-test. $P<0.05$ was assumed to be statistically significant.

\section{RESULTS}

Effect of systemic treatment with dTyr(CH2)5(Me)AVP or atenolol on the cardiovascular responses to hemorrhage in unanesthetized rats

$\operatorname{DTyr}\left(\mathrm{CH}_{2}\right)_{5}(\mathrm{Me}) A V P$. Systemic treatment with the selective $\mathrm{V}_{1}$-vasopressinergic receptor antagonist $\mathrm{dTy} r$ $\left(\mathrm{CH}_{2}\right)_{5}(\mathrm{Me})$ AVP $(50 \mu \mathrm{g} / \mathrm{kg}$, i.v., $n=5)$ did not affect baseline values of either MAP (102 \pm 0.7 vs. 102 $\pm 0.9 \mathrm{mmHg}, t=1.8, P=0.1)$ or HR (348 \pm 4 vs. 356 $\pm 3 \mathrm{bpm}, t=1.7, P=0.1)$. Analysis of the time-course curves of MAP and HR changes evoked by hemorrhage indicated a significant effect of treatment with dTyr $(\mathrm{CH} 2)$ 5(Me)AVP (DMAP: $F_{(1,136)}=46, \quad P<0.0001 ; \Delta \mathrm{HR}$ :
$\left.F_{(1,136)}=15, P=0.0002\right)$ and an effect over time ( $\triangle \mathrm{MAP}: F_{(16,136)}=16, P<0.0001 ; \Delta \mathrm{HR}: F_{(16,136)}=17$, $P<0.0001)$, as well as an interaction between treatment and time only for MAP response ( $\triangle \mathrm{MAP}$ : $F_{(16,136)}=14, \quad P<0.0001 ; \quad \Delta \mathrm{HR}: \quad F_{(16,136)}=0.8$, $P=0.7$ ) (Fig. 1). Post hoc analysis revealed that dTyr $\left(\mathrm{CH}_{2}\right)_{5}(\mathrm{Me})$ AVP increased the latency to the onset of hypotension during hemorrhage and slowed the postbleeding recovery of MAP $(P<0.05)$. Moreover, treatment with the $\mathrm{V}_{1}$-vasopressinergic receptor antagonist facilitated the tachycardiac response during hemorrhage $(P<0.05)$ (Fig. 1$)$.

Atenolol. Systemic treatment with the selective $\beta_{1}$ adrenoceptor antagonist atenolol ( $1 \mathrm{mg} / \mathrm{kg}$, i.v., $n=5$ ) did not affect baseline values of either MAP (95 \pm 0.8 vs. $97 \pm 1 \mathrm{mmHg}, t=1.4, P=0.2)$ or $\mathrm{HR}(352 \pm 3$ vs. $353 \pm 3 \mathrm{bpm}, t=0.8, P=0.4)$. Analysis of the timecourse curves of cardiovascular responses to hemorrhage indicated a significant effect of atenolol $\left(\Delta \mathrm{MAP}: F_{(1,136)}=15, P=0.0002 ; \Delta \mathrm{HR}: F_{(1,136)}=213\right.$, $P<0.0001)$ and an effect over time ( $\triangle \mathrm{MAP}$ : $F_{(16,136)}=10, \quad P<0.0001 ; \quad \Delta \mathrm{HR}: \quad F_{(16,136)}=4.3$, $P<0.0001)$, as well as an interaction between treatment and time ( $\triangle \mathrm{MAP}: F_{(16,136)}=5, P<0.0001$; $\Delta$ HR: $\quad F_{(1,136)}=8, \quad P<0.0001$ ) (Fig. 1). Post-hoc analysis revealed that atenolol increased the latency to the onset of hypotension during hemorrhage $(P<0.05)$
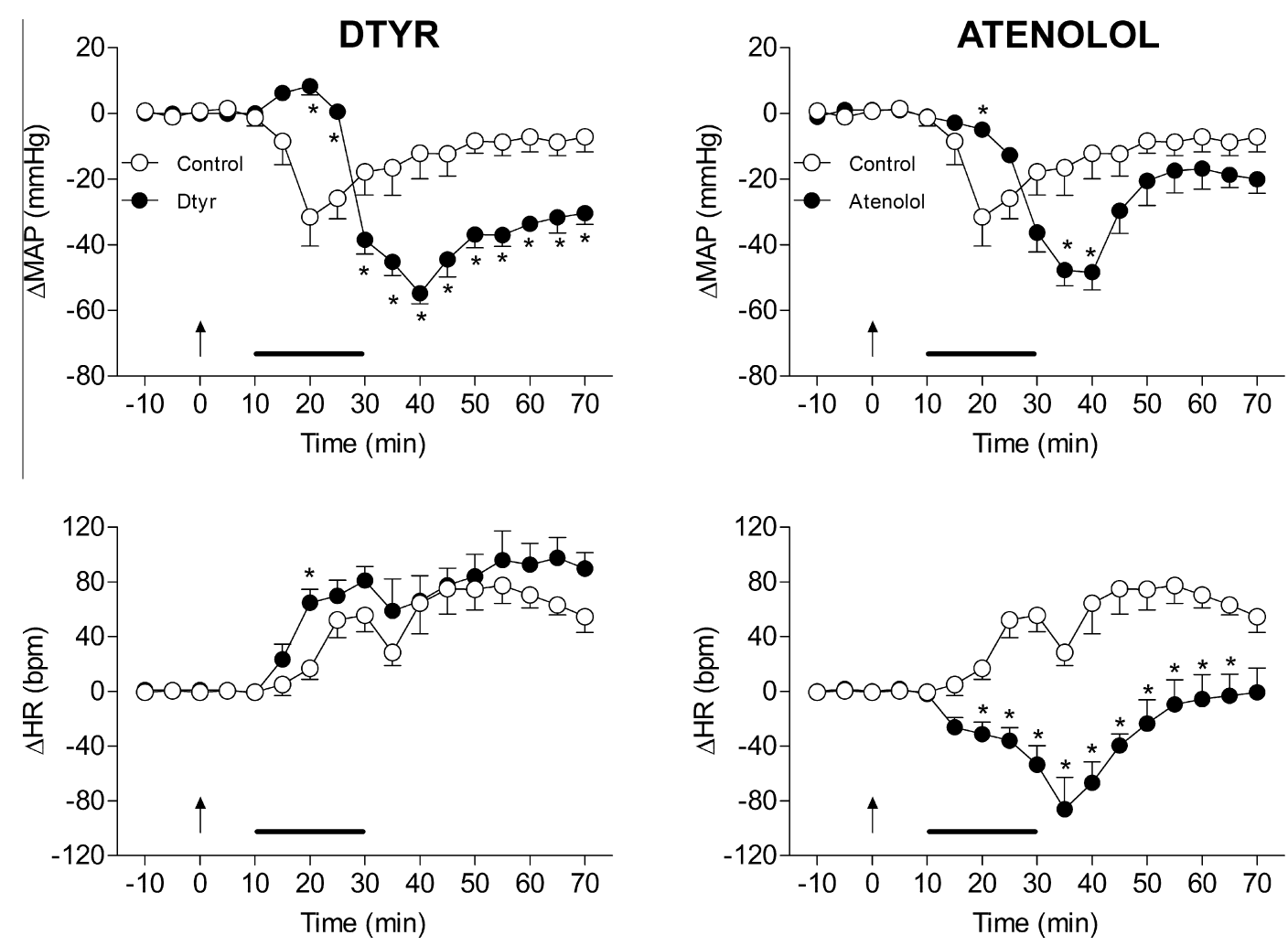

Fig. 1. Time-course curves of the effect of systemic treatment with saline (vehicle, $n=5$ ), the selective $\mathrm{V}_{1}$-vasopressinergic receptor antagonist $\mathrm{dTyr}\left(\mathrm{CH}_{2}\right)_{5}(\mathrm{Me}) \mathrm{AVP}(50 \mu \mathrm{g} / \mathrm{kg}, n=5)$ (left graphs), or the selective $\beta_{1}$-adrenoceptor antagonist atenolol (1 mg/kg, $\left.n=5\right)$ (right graphs) in MAP and HR changes induced by hemorrhage. Drug injections were done at time 0 , indicated by the arrow. Bleeding started at time 10 and finished at time 30; the black line represents the period of hemorrhage. Points represent the mean and bars the SEM. *, significantly different from control (vehicle) at the same timepoint (Bonferroni post hoc test, $P<0.05$ ). 
and reversed the hemorrhage-induced tachycardia into bradycardia $(P<0.05)$ (Fig. 1).

\section{Effect of PVN treatment with LY235959, NBQX or the combination of LY235959 + NBQX on the cardiovascular responses to hemorrhage in unanesthetized rats}

LY235959. Bilateral microinjection of the selective NMDA glutamate receptor antagonist LY23595 into the PVN $(2 \mathrm{nmol} / 100 \mathrm{~nL}, \quad n=5)$ did not affect baseline values of either MAP $(95 \pm 0.3$ vs. $95 \pm 1 \mathrm{mmHg}$, $t=0.3, P=0.7)$ or $\mathrm{HR}(372 \pm 3.2$ vs. $365 \pm 1.4 \mathrm{bpm}$, $t=2, P=0.06)$. Analysis of the time-course curves of cardiovascular changes evoked by hemorrhage indicated a significant effect of PVN treatment with LY235959 (DMAP: $F_{(1,136)}=16, \quad P<0.0001 ; \Delta \mathrm{HR}$ : $\left.F_{(1,136)}=73, \quad P<0.0001\right)$ and an effect over time $\left(\Delta \mathrm{MAP}: F_{(16,136)}=3, P=0.0008 ; \Delta \mathrm{HR}: F_{(16,136)}=10\right.$, $P<0.0001)$, as well as an interaction between treatment and time ( $\triangle \mathrm{MAP}: F_{(16,136)}=3, P=0.01$; $\left.\Delta \mathrm{HR}: F_{(16,136)}=6, \quad P<0.0001\right)$ (Fig. 2). Post hoc analysis revealed that LY235959 abolished the hemorrhage-induced hypotension $(P<0.05)$ and reduced the tachycardiac response during the posthemorrhage period $(P<0.05)$ (Fig. 2).

$N B Q X$. Bilateral microinjection of the selective nonNMDA glutamate receptor antagonist NBQX $(2 \mathrm{nmol} / 100 \mathrm{~nL}, n=5)$ into the PVN did not affect baseline values of MAP (92 \pm 0.7 vs. $93 \pm 0.5 \mathrm{mmHg}$, $t=1.3, \quad P=0.2)$ and $\mathrm{HR} \quad(377 \pm 2.8$ vs. 379 $\pm 1.3 \mathrm{bpm}, t=0.5, P=0.6)$. Analysis of the timecourse curves for hemorrhage-evoked cardiovascular changes indicated a significant effect of PVN treatment with NBQX ( $\triangle \mathrm{MAP}: F_{(1,136)}=21, P<0.0001 ; \Delta \mathrm{HR}$ : $\left.F_{(1,136)}=14, \quad P=0.0003\right)$ and an effect over time $\left(\Delta \mathrm{MAP}: F_{(16,136)}=17, P<0.0001 ; \Delta \mathrm{HR}: F_{(16,136)}=29\right.$, $P<0.0001)$, as well as an interaction between treatment and time ( $\triangle \mathrm{MAP}: F_{(16,136)}=2.4, P=0.003$; $\left.\Delta \mathrm{HR}: \quad F_{(16,136)}=2.4, \quad P=0.004\right) \quad$ (Fig. 2). Post-hoc analysis revealed that NBQX reduced the MAP recovery in the post-bleeding phase $(P<0.05)$ and decreased the tachycardia during both hemorrhagic $(P<0.05)$ and post-hemorrhagic periods $(P<0.05)$ (Fig. 2).

$L Y 235959+N B Q X$. Combined treatment of the PVN with LY235959 (2 nmol/100 nL) + NBQX (2 nmol/100 nL) $(n=5)$ did not affect baseline values of either MAP (104 \pm 0.4 vs. $105 \pm 0.7 \mathrm{mmHg}, t=0.6, P=0.6$ ) or $\mathrm{HR}$ $(337 \pm 5$ vs. $349 \pm 3 \mathrm{bpm}, t=1.6, P=0.1)$. Analysis of the time-course curves for cardiovascular responses to hemorrhage indicated a significant effect of treatment $\left(\Delta \mathrm{MAP}: F_{(1,136)}=57, \quad P<0.0001 ; \Delta \mathrm{HR}: F_{(1,136)}=6\right.$, $P=0.01)$ and an effect over time ( $\triangle \mathrm{MAP}$ : $F_{(16,136)}=4.2, \quad P<0.0001 ; \quad \Delta \mathrm{HR}: \quad F_{(16,136)}=10.2$, $P<0.0001)$, as well as an interaction between treatment and time $\left(\triangle \mathrm{MAP}: F_{(16,136)}=5.6, P<0.0001\right.$; $\Delta$ HR: $\left.F_{(16,136)}=3.7, P<0.0001\right)$ (Fig. 2). Post-hoc analysis revealed that combined treatment of the PVN with LY235959 + NBQX completely abolished the
LY
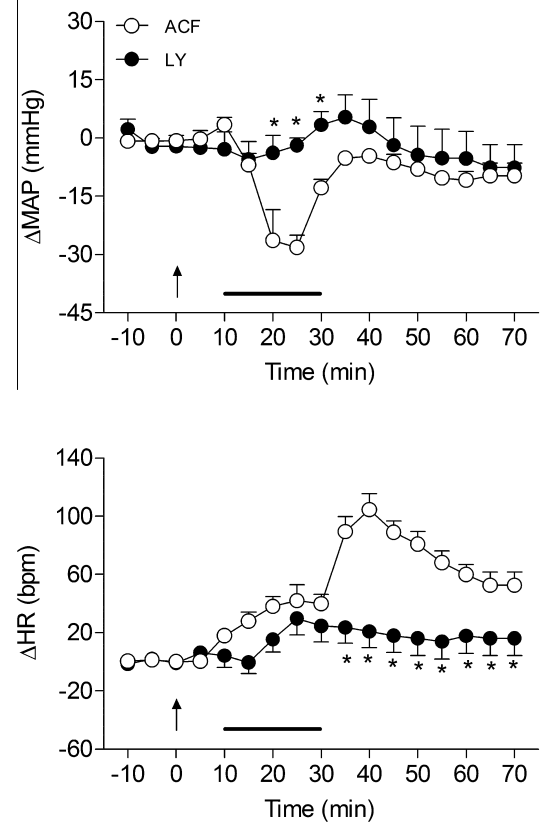

NBQX
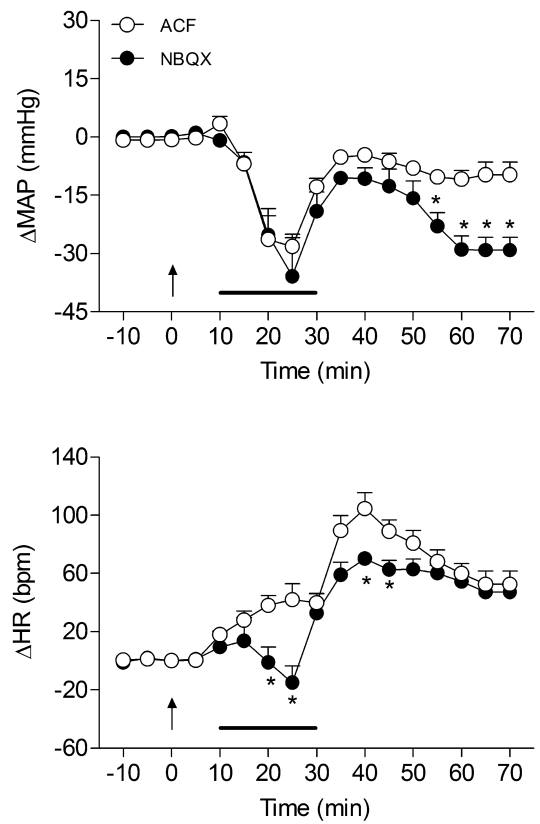

$L Y+N B Q X$
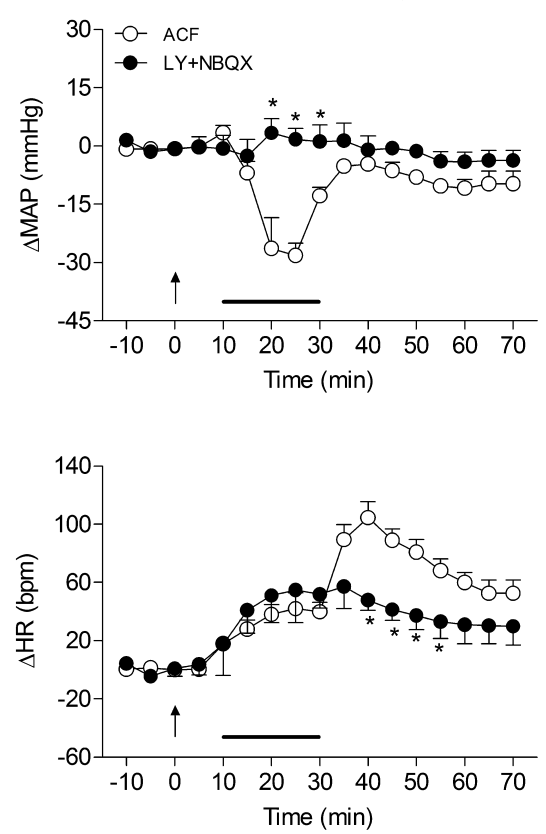

Fig. 2. Time-course curves of the effect of PVN treatment with vehicle (ACF, $100 \mathrm{~nL}, n=5$ ), the selective NMDA glutamate receptor antagonist LY235959 ( $2 \mathrm{nmol} / 100 \mathrm{~nL}, n=5$ ) (left graphs), the selective non-NMDA glutamate receptor antagonist NBQX $(2 \mathrm{nmol} / 100 \mathrm{~nL}, n=5)(\mathrm{middle}$ graphs), or combined treatment with LY235959 + NBQX (2 nmol/100 nL/drug, $n=5)$ (right graphs) on MAP and HR changes induced by hemorrhage. Drug injections were done at time 0 , indicated by the arrow. Bleeding started at time 10 and finished at time 30 ; the black line represents the period of hemorrhage. Points represent the mean and bars the SEM. ${ }^{*}$, significantly different from control (ACF) at the same timepoint (Bonferroni post hoc test, $P<0.05$ ). 
hemorrhage-induced hypotension $(P<0.05)$ and reduced the tachycardiac response in the posthemorrhage period $(P<0.05)$ (Fig. 2).

\section{Effect of PVN treatment with LY235959 in animals treated systemically with $\mathrm{dTyr}(\mathrm{CH} 2) 5(\mathrm{Me}) \mathrm{AVP}$ on the cardiovascular responses to hemorrhage in unanesthetized rats}

Bilateral microinjection of LY235959 into the PVN $(2 \mathrm{nmol} / 100 \mathrm{~nL})$ associated with systemic treatment with dTyr(CH2)5(Me)AVP $(50 \mu \mathrm{g} / \mathrm{kg})(n=5)$ did not affect baseline values of MAP $(97 \pm 3$ vs. $98 \pm 2 \mathrm{mmHg}$, $t=0.3, P=0.8)$ and $\mathrm{HR}(353 \pm 5$ vs. $345 \pm 7 \mathrm{bpm}$, $t=0.8, P=0.4$ ). Analysis of the time-course curves for HR responses to hemorrhage indicated a significant effect of treatment $\left(F_{(1,136)}=3.4, P=0.06\right)$ and an effect over time $\left(F_{(16,136)}=16.7, P<0.0001\right)$, as well as an interaction between treatment and time $\left(F_{(16,136)}=3.7, P=0.003\right)$ (Fig. 3). However, analysis of hemorrhage-evoked MAP changes did not indicate an effect of treatment $\left(F_{(1,136)}=2.5, P=0.1\right)$ or an interaction $\left(F_{(1,136)}=0.3, P=1.0\right)$ (Fig. 3). Post hoc analysis revealed that combined treatment with $d T y r$ $\left(\mathrm{CH}_{2}\right)_{5}(\mathrm{Me})$ AVP systemically and LY235959 in the PVN reduced the tachycardiac response during the post-
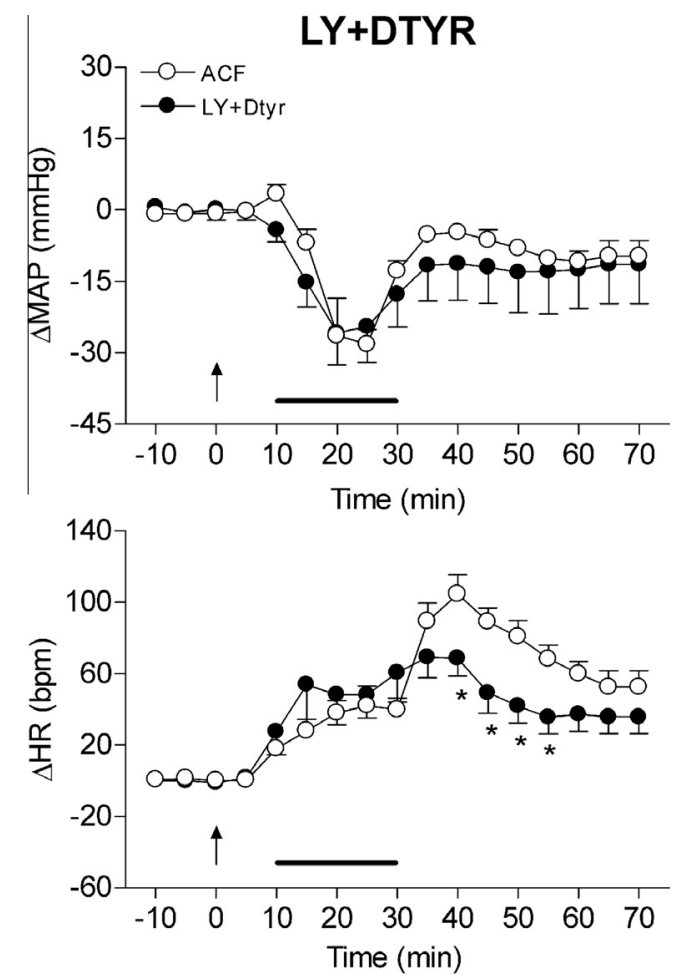

Fig. 3. Time-course curves of the effect of vehicle (ACF, $100 \mathrm{~nL}$, $n=5$ ) microinjected into the PVN (open circles) or the selective NMDA receptor antagonist LY235959 $(2 \mathrm{nmol} / 100 \mathrm{~nL})$ microinjected into the PVN associated with systemic treatment with the $V_{1}$ vasopressinergic receptor antagonist dTyr $\left(\mathrm{CH}_{2}\right)_{5}(\mathrm{Me}) \mathrm{AVP}(50 \mu \mathrm{g} /$ $\mathrm{kg})(n=5)$ (solid circles) on MAP and HR changes induced by hemorrhage. Drug injections were done at time 0 , indicated by the arrow. Bleeding started at time 10 and finished at time 30; the black line represents the period of hemorrhage. Points represent the mean and bars the SEM. ", significantly different from control (ACF) at the same timepoint (Bonferroni post hoc test, $P<0.05$ ). hemorrhagic period $(P<0.05)$ without affecting the blood pressure response (Fig. 3).

\section{Determination of microinjection sites in the PVN}

A diagrammatic representation showing bilateral microinjection sites in the PVN of all animals used in the present study is presented in Fig. 4. Also, Fig. 4 presents a photomicrograph of a coronal brain section depicting bilateral microinjection sites in the PVN of one representative animal.

\section{DISCUSSION}

Results obtained in humans and animals have indicated that hemorrhage-induced cardiovascular responses occur in three progressive phases (Evans et al., 2001; Troy et al., 2003). In phase I, called compensatory, there is an increase in vasomotor and cardiac sympathetic
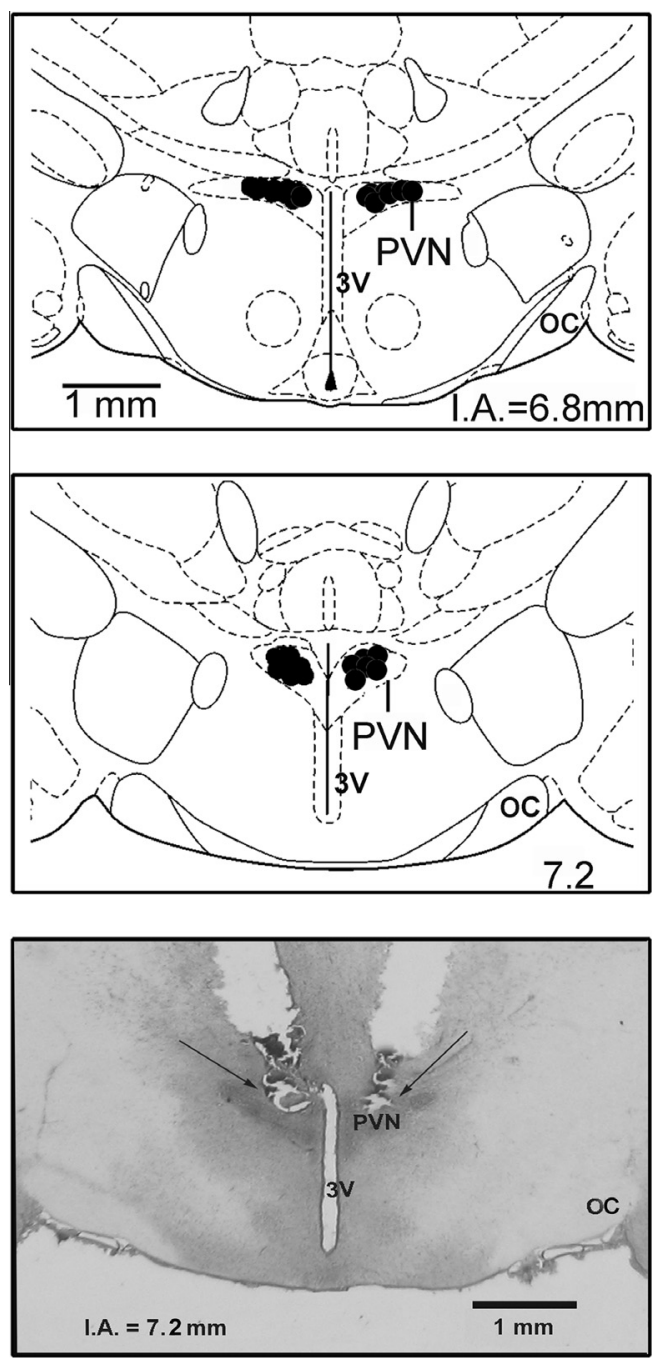

Fig. 4. Diagrammatic representation showing bilateral microinjection sites in the PVN of all animals used in the present study and a representative figure of a coronal section of a rat brain depicting the site of bilateral microinjection in the PVN. The center of the microinjection is indicated by arrows. IA - distance from interaural line, PVN - paraventricular nucleus of the hypothalamus; OC chiasm optic tract; $3 \mathrm{~V}$ - third ventricle. 
drives and a decrease in cardiac parasympathetic activity, which leads to the maintenance of blood pressure within normal levels and to a HR increase (Victor et al., 1989; Schadt and Ludbrook, 1991; Evans et al., 1994; Thrasher and Shifflett, 2001; Troy et al., 2003). When bleeding reaches about a $30 \%$ decrease in total blood volume, phase II, called decompensatory, is established. This phase is characterized by rapid hypotension and variable responses in $\mathrm{HR}$, which are mediated by a paradoxical cardiac parasympathetic stimulation and sympathetic nerve activity inhibition (Ludbrook et al., 1988; Victor et al., 1989; Schadt and Ludbrook, 1991; Scislo and O'Leary, 2006). Although during phase II an increase in renin-angiotensin-aldosterone activity (Michailov et al., 1987; Starc and Stalcup, 1987; Botelho et al., 1994) and circulating vasopressin occurs (Share, 1988; Shoji et al., 1993; Kakiya et al., 2000), these responses are not enough to sustain the blood pressure at normal levels resulting in an abrupt blood pressure fall. If the bleeding stops, phase III occurs, called recompensatory, when MAP and HR return to near basal levels (Schadt and Ludbrook, 1991; Troy et al., 2003) due to, at least in part, increased circulating levels of vasopressin and cardiac sympathetic activation (Kakiya et al., 2000; Troy et al., 2003).

\section{Role of circulating vasopressin and peripheral $\beta$-adrenoceptors in the cardiovascular responses to hemorrhage}

The present findings show a postponement of the hypotension during hemorrhage and a blunting of MAP post-bleeding recovery in animals treated with the $\mathrm{V}_{1}$-vasopressinergic receptor antagonist $\operatorname{dTyr}\left(\mathrm{CH}_{2}\right)_{5}(\mathrm{Me})$ AVP. These results are in line with previous results suggesting an important role for vasopressin in the recovery following hemorrhage (Zerbe et al., 1982; Chapman et al., 1986; Johnson et al., 1988; Fujisawa et al., 1994; Imai et al., 1996), which seems to be mediated by both central and peripheral actions of the peptide (Johnson et al., 1988). However, previous studies have indicated an involvement of vasopressin in the paradoxical sympathoinhibitory response during hemorrhagic shock (Peuler et al., 1990; Fujisawa et al., 1994; Budzikowski et al., 1996; Imai et al., 1996), thus supporting our results of postponement of the hypotension in animals treated with $\mathrm{dTyr}\left(\mathrm{CH}_{2}\right)_{5}(\mathrm{Me}) \mathrm{AVP}$. Indeed, vasopressin facilitates baroreflex-mediated inhibition of sympathetic activity (Share, 1988), which may contribute to the sympathoinhibitory action during hemorrhage. However, a role for central $\mathrm{V}_{1}$-vasopressinergic receptors in eliciting hypotension during hemorrhage has also been suggested (Budzikowski et al., 1996). In fact, vasopressin acting on the brainstem inhibits sympathetic activity (Suzuki et al., 1989). In addition, a mechanism of central action for circulating vasopressin would be the activation of $V_{1}$-receptors in circumventricular organs lacking blood-brain barrier, such as the area postrema, which possesses vasopressinergic neurons and could activate a downstream pathway that in turn inhibits sympathetic outputs (Suzuki et al., 1989; Scislo et al., 2005; Scislo and O'Leary, 2006; Yang and Hwang, 2007).
Antagonism of peripheral $\beta_{1}$-adrenoceptors reversed the tachycardiac response into a bradycardia. The present findings corroborate previous studies indicating an involvement of cardiac sympathetic activity in hemorrhage-induced tachycardia (Hintze and Vatner, 1982), which is possibly mediated by an increase in catecholamine release from the adrenal medulla, since inhibition of sympathetic nerve activity has been reported during hemorrhagic shock (Ludbrook et al., 1988; Victor et al., 1989; Schadt and Ludbrook, 1991; Scislo and O'Leary, 2006; Frithiof et al., 2011). The bradycardia observed in atenolol-treated animals is in line with results indicating a coactivation of cardiac sympathetic and parasympathetic activity during hemorrhagic shock (Gonzalez Gonzalez et al., 1995; Porter et al., 2009).

Blockade of $\beta_{1}$-adrenoceptors also postponed the hypotension during hemorrhage and accentuated this response during the post-bleeding period. The enhanced hypotension is possibly related to a conversion of the tachycardiac response into bradycardia, thus implicating the HR response as an important compensatory response counteracting the arterial pressure decrease during critical periods of hemorrhagic shock. The reduction of hypotension during hemorrhage in atenololtreated animals was unexpected. A possible explanation could be the blockade of vascular $\beta$-adrenoceptors, whose activation causes vascular smooth muscle relaxation. Nevertheless, further experiments are necessary to clarify this effect.

\section{Involvement of PVN glutamate neurotransmission in cardiovascular responses to hemorrhage}

Increase in immunoreactive Fos protein in vasopressinergic and sympathetic preautonomic neurons was observed in the PVN following bleeding (Badoer et al., 1993; Krukoff, 1993; Roberts et al., 1993; Petrov et al., 1995; Badoer and Merolli, 1998). Indeed, previous studies have reported that either lesion or knife cut deafferentation of the PVN reduced the neuroendocrine responses to hemorrhage; however, without affecting arterial pressure and HR responses (Darlington et al., 1988; Blair et al., 1998). Therefore, to the best of our knowledge, the present findings provide the first direct evidence of PVN involvement in hemorrhage-evoked cardiovascular responses. The absence of evidence in previous studies may be due to the use of lesions instead of a specific neurochemical blockade (i.e., glutamatergic), an approach used in the present experiment. Indeed, previous studies reported that although lesion or nonselective synaptic blockade of the PVN did not affect cardiovascular parameters (Darlington et al., 1988; Callahan et al., 1992; Busnardo et al., 2010; Crestani et al., 2010), specific blockade of local signaling mechanisms (e.g., nitrergic, GABAergic, and glutamatergic) induced arterial pressure and HR changes (Busnardo et al., 2010; Martins-Pinge et al., 2012). These results are supported by evidence for the existence of both excitatory and inhibitory inputs to the PVN, so that the control of cardiovascular function by this nucleus is only revealed after blockade of specific local neurochemical mechanisms. 
PVN glutamate neurotransmission has been implicated in the control of autonomic, cardiovascular, and neuroendocrine activities (Curras-Collazo and Dao, 1999; Kawasaki et al., 2005; Busnardo et al., 2009, 2012, 2013; Crestani et al., 2010). To determine the role played by ionotropic glutamate receptors of the PVN in hemorrhage-induced cardiovascular responses, we pretreated the PVN with selective NMDA and/or non-NMDA glutamate receptor antagonists. PVN treatment with the NMDA receptor antagonist LY235959 reduced the tachycardiac response in the post-hemorrhagic period. Together with the findings that pretreatment with a $\beta_{1}$-adrenoceptor antagonist abolished the hemorrhageinduced tachycardia, the LY235959 results provide evidence that PVN NMDA receptors contribute to cardiac sympathetic activation during the post-bleeding period. Indeed, previous results indicated a high expression of NMDA receptors throughout the PVN, including the preautonomic parvocellular neurons (Herman et al., 2000). Moreover, a wide range of studies has shown that activation of NMDA glutamate receptors in the PVN increases sympathetic nerve activity (Badoer, 1996; Chen et al., 2003; Li et al., 2008; Busnardo et al., 2009).

Conversely, blockade of PVN NMDA receptors inhibited the hypotension induced by hemorrhage, indicating that activation of these receptors in the PVN contributes to hemorrhagic shock. Two mechanisms could trigger this effect: firstly, the activation of NMDA glutamate receptors located in GABAergic neurons can increase local GABA release, which in turn activates $\mathrm{GABA}_{\mathrm{A}}$ receptors causing sympathoinhibition-mediated hypotension (Martin et al., 1991; Decavel and van den Pol, 1992; Boudaba et al., 1996; Zhang and Patel, 1998; Mathew and Hablitz, 2011); secondly, PVN NMDA glutamate receptors can modulate vasopressin release into the bloodstream during hemorrhagic shock (Busnardo et al., 2009, 2012). To test this hypothesis, we investigated the effect of intra-PVN treatment with LY235959 in animals intravenously pretreated with the $\mathrm{V}_{1}$-vasopressinergic receptor antagonist $\mathrm{dTyr}\left(\mathrm{CH}_{2}\right)_{5}(\mathrm{Me})$ AVP. Systemic treatment with d $\operatorname{Tyr}\left(\mathrm{CH}_{2}\right)_{5}(\mathrm{Me}) \mathrm{AVP}$ inhibited the LY235959-induced blockade of the hemorrhageevoked hypotension, suggesting that the involvement of PVN NMDA receptors in hemorrhagic shock is dependent on a modulation of vasopressin release to the circulation. Previous results have indicated an inhibitory role of PVN NMDA receptors on vasopressin release into the bloodstream (Badoer, 1996; Busnardo et al., 2009, 2012), thus suggesting that inhibition of hemorrhagic shock following blockade of PVN NMDA receptors may be mediated by an increase of vasopressin release into the circulation. Excessive circulating vasopressin levels may allow the potent vasoconstrictor action of vasopressin to overcome the sympathoinhibitory effect, thus protecting against hemorrhagic shock. However, expression of NMDA receptors has been reported in PVN magnocellular neurosecretory neurons (Herman et al., 2000). Therefore, we cannot exclude the possibility that PVN NMDA receptors are implicated in vasopressin release during hemorrhage, so that inhibition of hemorrhagic shock in animals treated with LY235959 would be mediated by a reduction of vasopressin-mediated sympathoinhibition.

The ventrolateral column of the periaqueductal gray (VIPAG) in the midbrain has been demonstrated to play a key role in the decompensatory responses during hemorrhage (Cavun and Millington, 2001; Troy et al., 2003; Dean, 2004). Although there is evidence of activation of downstream vasodepressor signals in the caudal midline medulla (CMM) (Vagg et al., 2008), vIPAG neurons also control vasopressin release into the circulation (Pelosi et al., 2008). Therefore, the vIPAG may be an important source of PVN glutamatergic inputs involved in decompensatory responses through the control of vasopressin release.

Treatment of the PVN with the selective non-NMDA glutamate receptor antagonist NBQX slowed the postbleeding recovery of MAP. Our results obtained in animals treated systemically with a $V_{1}$-vasopressinergic receptor antagonist indicated an important role of vasopressin in recovery from hypotension associated with hemorrhage, thus suggesting that control of arterial pressure during the recompensatory phase exerted by PVN non-NMDA receptors may be mediated by activation of magnocellular neurosecretory neurons. Indeed, previous studies indicated the expression of non-NMDA receptors in vasopressin-containing magnocellular neurons (Herman et al., 2000). Accordingly, we have previously reported that control of vasopressin release from PVN magnocellular cells by local glutamatergic neurotransmission is mediated mainly by the activation of non-NMDA receptors (Busnardo et al., 2009 , 2012). Furthermore, several studies have shown an involvement of PVN non-NMDA glutamate receptors in vasopressin-mediated cardiovascular responses (Scopinho et al., 2008; Busnardo et al., 2009; Crestani et al., 2009; Pelosi et al., 2015).

PVN treatment with NBQX also reversed the tachycardiac response during the hemorrhagic shock into bradycardia, and reduced the HR increase during the post-hemorrhagic period. Pharmacological and electrophysiological studies have demonstrated that activation of PVN non-NMDA glutamate receptors increases sympathetic nerve activity (van den Pol et al., 1990; Wuarin and Dudek, 1991; Herman et al., 2000; Chen et al., 2003; Li et al., 2008), which support the involvement of this receptor in the sympathetic-mediated tachycardiac response induced by hemorrhage. Coadministration of the NMDA receptor antagonist abolished the bradycardia during hemorrhagic shock observed in animals treated with the non-NMDA receptor antagonist, implicating local NMDA receptors in negative chronotropic response during hemorrhagic shock (Gonzalez Gonzalez et al., 1995; Porter et al., 2009). Furthermore, this finding reinforces the idea of an involvement of PVN NMDA receptors in the paradoxical sympathoinhibition during hemorrhagic shock. As discussed above, this action seems to be mediated by a modulation of vasopressin release to the circulation, which in turn inhibits sympathetic activity via central and peripheral actions (Share, 1988; Suzuki et al., 1989; Badoer, 1996; Budzikowski 

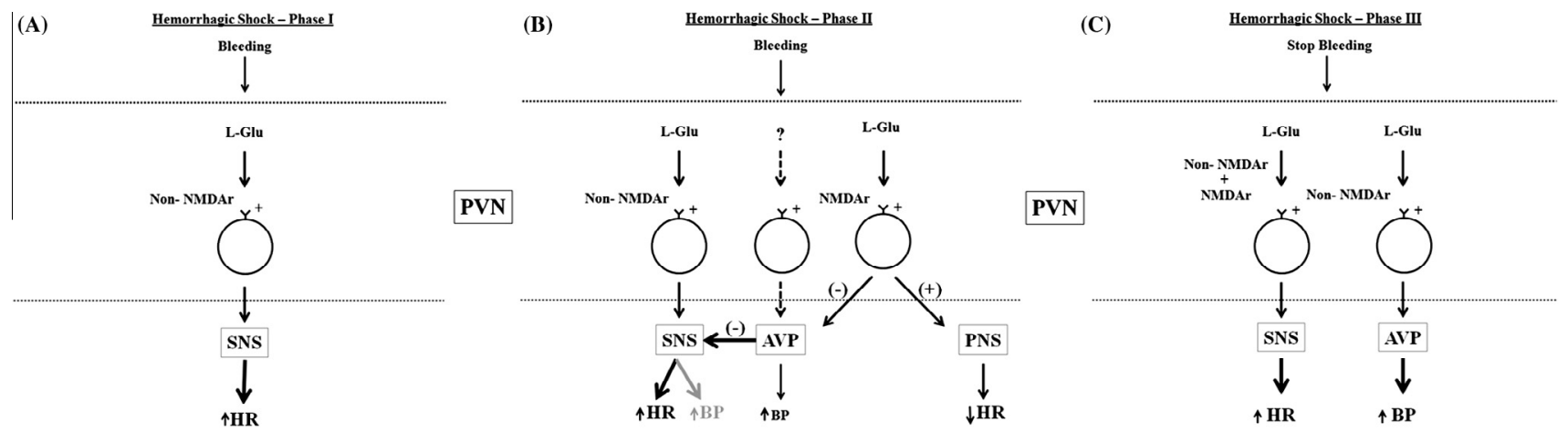

Fig. 5. Schematic representation illustrating the role of NMDA and non-NMDA glutamate receptors within the PVN controlling the three phases of hemorrhage-induced cardiovascular responses through modulation of vasopressin (AVP) release into the circulation and sympathetic (SNS) and parasympathetic (PNS) nervous system responses.

et al., 1996). However, previous results have also indicated that PVN glutamate neurotransmission facilitates cardiac parasympathetic activity (Crestani et al., 2010), suggesting that NMDA receptor-mediated negative chronotropic effect during hemorrhagic shock may be mediated by cardiac sympathetic inhibition and/or parasympathetic inhibition. However, the tachycardia during the postbleeding period seems to be mediated by an activation of both NMDA and non-NMDA glutamate receptors in the PVN.

A schematic representation sketching the role of ionotropic glutamate receptors within the PVN in the three phases of hemorrhage-induced cardiovascular responses is presented in Fig. 5. Taken together, results reported in the present study indicate an involvement of PVN non-NMDA receptors in the sympathetic-mediated tachycardia during phase I and II, whereas both NMDA and non-NMDA receptors mediate this response during phase III. Furthermore, activation of NMDA receptors during phase II triggers decompensatory responses through a modulation of vasopressin release, whereas non-NMDA receptors are involved in vasopressin release during phase III.

\section{CONCLUSION}

In summary, the present findings confirm an involvement of circulating vasopressin in hemorrhagic shock, as well as in MAP recovery during the post-bleeding period. Cardiac sympathetic activity mediates hemorrhageinduced tachycardiac responses, which seem to be buffered by cardiac parasympathetic activation. Importantly, the present study provides the first evidence of a role of PVN glutamatergic neurotra nsmission in hemorrhage-induced cardiovascular changes. Our results indicate an involvement of NMDA receptors of the PVN in hemorrhagic shock, which is mediated by controlling vasopressin release to the circulation and a negative chronotropic effect. However, this receptor also seems to contribute to post-bleeding recovery, being involved in the tachycardiac response. Non-NMDA receptors in the PVN are involved in the tachycardiac response during hemorrhage and the post- bleeding period. Moreover, this receptor is involved in the post-bleeding recovery of arterial pressure.

Acknowledgments-We acknowledge Ms. Ivanilda A.C. Fortunato and Laura H.A. de Camargo for technical assistance. Aline Fassini is a graduate student and recipient of FAPESP fellowship (2013/00249-9) and Cristiane Busnardo [Postdoctoral National Program (PNPD) of CAPES] is a post-doctoral fellow in the Department of Pharmacology of the School of Medicine of Ribeirão Preto-USP. The present research was supported by grants from CNPq (474477/2013-4) and FAEPA-HCFMRP-USP.

\section{REFERENCES}

Abjean $\mathrm{J}$ (1986) Occlusal requirements in prosthetic reconstruction in view of deep periodontal lesions. J Parodontol 5:353-363.

Badoer E (1996) Cardiovascular role of parvocellular neurons in the paraventricular nucleus of the hypothalamus. News Physiol Sci 11:43-47.

Badoer E, McKinley MJ, Oldfield BJ, McAllen RM (1993) A comparison of hypotensive and non-hypotensive hemorrhage on Fos expression in spinally projecting neurons of the paraventricular nucleus and rostral ventrolateral medulla. Brain Res 610:216-223.

Badoer E, Merolli J (1998) Neurons in the hypothalamic paraventricular nucleus that project to the rostral ventrolateral medulla are activated by haemorrhage. Brain Res 791:317-320.

Bellamy RF (1984) The causes of death in conventional land warfare: implications for combat casualty care research. Mil Med 149:55-62.

Bisset GW, Chowdrey HS (1988) Control of release of vasopressin by neuroendocrine reflexes. Q J Exp Physiol 73:811-872.

Blair ML, Want A, Olschowka JA, Piekut D (1998) Role of paraventricular nucleus parvicellular neurons in the compensatory responses to graded hemorrhage. Am J Physiol 275:R278-R285.

Botelho LM, Block CH, Khosla MC, Santos RA (1994) Plasma angiotensin (1-7) immunoreactivity is increased by salt load, water deprivation, and hemorrhage. Peptides 15:723-729.

Boudaba C, Szabo K, Tasker JG (1996) Physiological mapping of local inhibitory inputs to the hypothalamic paraventricular nucleus. J Neurosci 16:7151-7160.

Budzikowski AS, Paczwa P, Szczepanska-Sadowska E (1996) Central V1 AVP receptors are involved in cardiovascular adaptation to hypovolemia in WKY but not in SHR. Am J Physiol 271:H1057-H1064.

Busnardo C, Alves FH, Crestani CC, Scopinho AA, Resstel LB, Correa FM (2013) Paraventricular nucleus of the hypothalamus glutamate neurotransmission modulates autonomic, 
neuroendocrine and behavioral responses to acute restraint stress in rats. Eur Neuropsychopharmacol 23:1611-1622.

Busnardo C, Crestani CC, Resstel LB, Tavares RF, AntunesRodrigues J, Correa FM (2012) lonotropic glutamate receptors in hypothalamic paraventricular and supraoptic nuclei mediate vasopressin and oxytocin release in unanesthetized rats. Endocrinology 153:2323-2331.

Busnardo C, Tavares RF, Correa FMA (2007) Cardiovascular effects of L-glutamate microinjection in the supraoptic nucleus of unanaesthetized rats. Neuropharmacology 52:1378-1384.

Busnardo C, Tavares RF, Correa FMA (2009) Role of N-methyl-Daspartate and non-N-methyl-D-aspartate receptors in the cardiovascular effects of L-glutamate microinjection into the hypothalamic paraventricular nucleus of unanesthetized rats. $J$ Neurosci Res. 101002/jnr22028.

Busnardo C, Tavares RF, Resstel LB, Elias LL, Correa FM (2010) Paraventricular nucleus modulates autonomic and neuroendocrine responses to acute restraint stress in rats. Auton Neurosci 158:51-57.

Callahan MF, Thore CR, Sundberg DK, Gruber KA, O'Steen K, Morris $M$ (1992) Excitotoxin paraventricular nucleus lesions: stress and endocrine reactivity and oxytocin mRNA levels. Brain Res 597:8-15.

Cavun S, Millington WR (2001) Evidence that hemorrhagic hypotension is mediated by the ventrolateral periaqueductal gray region. Am J Physiol Regul Integr Comp Physiol 281: R747-R752.

Chapman JT, Hreash F, Laycock JF, Walter SJ (1986) The cardiovascular effects of vasopressin after haemorrhage in anaesthetized rats. J Physiol 375:421-434.

Chen QH, Haywood JR, Toney GM (2003) Sympathoexcitation by PVN-injected bicuculline requires activation of excitatory amino acid receptors. Hypertension 42:725-731.

Cherkas D (2011) Traumatic hemorrhagic shock: advances in fluid management. Emerg Med Pract 13:1-19. quiz 19-20.

Crestani CC, Alves FH, Busnardo C, Resstel LB, Correa FM (2010) $\mathrm{N}$-methyl-D-aspartate glutamate receptors in the hypothalamic paraventricular nucleus modulate cardiac component of the baroreflex in unanesthetized rats. Neurosci Res 67:317-326.

Crestani CC, Busnardo C, Tavares RF, Alves FH, Correa FM (2009) Involvement of hypothalamic paraventricular nucleus non- $\mathrm{N}$ methyl-D-aspartate receptors in the pressor response to noradrenaline microinjected into the bed nucleus of the stria terminalis of unanesthetized rats. Eur J Neurosci 29:2166-2176.

Cunningham Jr ET, Sawchenko PE (1991) Reflex control of magnocellular vasopressin and oxytocin secretion. Trends Neurosci 14:406-411.

Cunningham JT, Bruno SB, Grindstaff RR, Grindstaff RJ, Higgs KH, Mazzella D, Sullivan MJ (2002) Cardiovascular regulation of supraoptic vasopressin neurons. Prog Brain Res 139:257-273.

Cunningham JT, Penny ML, Murphy D (2004) Cardiovascular regulation of supraoptic neurons in the rat: synaptic inputs and cellular signals. Prog Biophys Mol Biol 84:183-196.

Curras-Collazo MC, Dao J (1999) Osmotic activation of the hypothalamo-neurohypophysial system reversibly downregulates the NMDA receptor subunit, NR2B, in the supraoptic nucleus of the hypothalamus. Brain Res Mol Brain Res 70:187-196.

Cuschieri J, Johnson JL, Sperry J, West MA, Moore EE, Minei JP, Bankey PE, Nathens AB, Cuenca AG, Efron PA, Hennessy L, Xiao W, Mindrinos MN, McDonald-Smith GP, Mason PH, Billiar TR, Schoenfeld DA, Warren HS, Cobb JP, Moldawer LL, Davis RW, Maier RV, Tompkins RG (2012) Benchmarking outcomes in the critically injured trauma patient and the effect of implementing standard operating procedures. Ann Surg 255:993-999.

Darlington DN, Shinsako J, Dallman MF (1988) Paraventricular lesions: hormonal and cardiovascular responses to hemorrhage. Brain Res 439:289-301.

Dean C (2004) Hemorrhagic sympathoinhibition mediated through the periaqueductal gray in the rat. Neurosci Lett 354:79-83.

Decavel C, van den Pol AN (1992) Converging GABA- and glutamate-immunoreactive axons make synaptic contact with identified hypothalamic neurosecretory neurons. J Comp Neurol 316:104-116.

Dos Reis DG, Fortaleza EA, Tavares RF, Correa FM (2014) Role of the autonomic nervous system and baroreflex in stress-evoked cardiovascular responses in rats. Stress 17:362-372.

Evans RG, Ludbrook J, Ventura S (1994) Role of vagal afferents in the haemodynamic response to acute central hypovolaemia in unanaesthetized rabbits. J Auton Nerv Syst 46:251-260.

Evans RG, Ventura S, Dampney RA, Ludbrook J (2001) Neural mechanisms in the cardiovascular responses to acute central hypovolaemia. Clin Exp Pharmacol Physiol 28:479-487.

Frithiof R, Ramchandra R, Hood SG, May CN (2011) Hypertonic sodium resuscitation after hemorrhage improves hemodynamic function by stimulating cardiac, but not renal, sympathetic nerve activity. Am J Physiol Heart Circ Physiol 300:H685-H692.

Fujisawa Y, Miyatake A, Hayashida Y, Aki Y, Kimura S, Tamaki T, Abe $Y$ (1994) Role of vasopressin on cardiovascular changes during hemorrhage in conscious rats. Am J Physiol 267: H1713-H1718.

Garrioch MA (2004) The body's response to blood loss. Vox Sang 87 (Suppl 1):74-76.

Gonzalez Gonzalez J, Cordero Valeriano JJ, Feria Rodriguez M (1995) Autonomic mediation of short-term cardiovascular oscillations after acute hemorrhage in conscious rats. J Auton Nerv Syst 55:123-130.

Gutierrez G, Reines HD, Wulf-Gutierrez ME (2004) Clinical review: hemorrhagic shock. Crit Care 8:373-381.

Herman JP, Eyigor O, Ziegler DR, Jennes L (2000) Expression of ionotropic glutamate receptor subunit mRNAs in the hypothalamic paraventricular nucleus of the rat. J Comp Neurol 422:352-362.

Hintze TH, Vatner SF (1982) Cardiac dynamics during hemorrhage. Relative unimportance of adrenergic inotropic responses. Circ Res 50:705-713.

Imai Y, Kim CY, Hashimoto J, Minami N, Munakata M, Abe K (1996) Role of vasopressin in neurocardiogenic responses to hemorrhage in conscious rats. Hypertension 27:136-143.

Jaworski RL, Blair ML (2004) Lesions of the dorsal noradrenergic bundle augment the renin response to blood loss but do not alter hypothalamic Fos expression. Brain Res Bull 63:451-459.

Johnson JV, Bennett GW, Hatton R (1988) Central and systemic effects of a vasopressin V1 antagonist on MAP recovery after haemorrhage in rats. J Cardiovasc Pharmacol 12:405-412.

Kakiya S, Arima H, Yokoi H, Murase T, Yambe Y, Oiso Y (2000) Effects of acute hypotensive stimuli on arginine vasopressin gene transcription in the rat hypothalamus. Am J Physiol Endocrinol Metab 279:E886-E892.

Kawasaki A, Hoshi K, Kawano M, Nogami H, Yoshikawa H, Hisano S (2005) Up-regulation of VGLUT2 expression in hypothalamicneurohypophysial neurons of the rat following osmotic challenge. Eur J Neurosci 22:672-680.

Krukoff TL (1993) Expression of c-fos in studies of central autonomic and sensory systems. Mol Neurobiol 7:247-263.

Krukoff TL (1999) Central actions of nitric oxide in regulation of autonomic functions. Brain Res Brain Res Rev 30:52-65.

Kuypers HGJM, Maisky VA (1975) Retrograde axonal transport of horseradish peroxidase from spinal cord to brainstem cell groups in cats. Neurosci Lett 1:9-14.

Levi MM, Vink R, de Jonge E (2002) Management of bleeding disorders by prohemostatic therapy. Int J Hematol 76(Suppl 2):139-144.

Li DP, Yang Q, Pan HM, Pan HL (2008) Pre- and postsynaptic plasticity underlying augmented glutamatergic inputs to hypothalamic presympathetic neurons in spontaneously hypertensive rats. J Physiol 586:1637-1647.

Li YW, Dampney RA (1994) Expression of Fos-like protein in brain following sustained hypertension and hypotension in conscious rabbits. Neuroscience 61:613-634.

Liu L, Tian K, Zhu Y, Ding X, Li T (2013) Delta opioid receptor antagonist, $\mathrm{ICl} 174,864$, is suitable for the early treatment of uncontrolled hemorrhagic shock in rats. Anesthesiology 119:379-388. 
Loewy AD (1990) Central autonomic pathways. In: Loewy AD, Spyer KM, editors. Central Regulation of Autonomic Functions. New York: Oxford University Press. p. 88-103.

Ludbrook J, Potocnik SJ, Woods RL (1988) Simulation of acute haemorrhage in unanaesthetized rabbits. Clin Exp Pharmacol Physiol 15:575-584.

Malinoski DJ, Patel MS, Lush S, Willis ML, Navarro S, Schulman D, Querantes T, Leinen-Duren R, Salim A (2012) Impact of compliance with the American College of Surgeons trauma center verification requirements on organ donation-related outcomes. J Am Coll Surg 215:186-192.

Martin DS, Segura T, Haywood JR (1991) Cardiovascular responses to bicuculline in the paraventricular nucleus of the rat. Hypertension 18:48-55.

Martins-Pinge MC, Mueller PJ, Foley CM, Heesch CM, Hasser EM (2012) Regulation of arterial pressure by the paraventricular nucleus in conscious rats: interactions among glutamate, GABA, and nitric oxide. Front Physiol 3:490.

Mathew SS, Hablitz JJ (2011) Presynaptic NMDA receptors mediate IPSC potentiation at GABAergic synapses in developing rat neocortex. PLoS One 6:e17311.

Michailov ML, Schad H, Dahlheim H, Jacob IC, Brechtelsbauer H (1987) Renin-angiotensin system responses of acute graded hemorrhage in dogs. Circ Shock 21:217-224.

Moore FA, Sauaia A, Moore EE, Haenel JB, Burch JM, Lezotte DC (1996) Postinjury multiple organ failure: a bimodal phenomenon. J Trauma 40:501-510. discussion 510-502.

Paxinos G, Watson C (1986) The rat brain in stereotaxic coordinates. Sydney: Harcourt Brace Jovanovich.

Pelosi GG, Busnardo C, Tavares RF, Correa FM (2015) Involvement of non-NMDA glutamate receptors of the hypothalamic paraventricular nucleus in the cardiovascular response to the microinjection of noradrenaline into the dorsal periaqueductal gray area of rats. Brain Res.

Pelosi GG, Tavares RF, Antunes-Rodrigues J, Correa FM (2008) Cardiovascular responses to noradrenaline microinjection in the ventrolateral periaqueductal gray of unanesthetized rats. J Neurosci Res 86:712-719.

Petrov T, Harris KH, MacTavish D, Krukoff TL, Jhamandas JH (1995) Hypotension induces Fos immunoreactivity in $\mathrm{NADPH}-$ diaphorase positive neurons in the paraventricular and supraoptic hypothalamic nuclei of the rat. Neuropharmacology 34:509-514.

Peuler JD, Schmid PG, Morgan DA, Mark AL (1990) Inhibition of renal sympathetic activity and heart rate by vasopressin in hemorrhaged diabetes insipidus rats. Am J Physiol 258: H706-H712.

Porter K, Ahlgren J, Stanley J, Hayward LF (2009) Modulation of heart rate variability during severe hemorrhage at different rates in conscious rats. Auton Neurosci 150:53-61.

Pyner S, Cleary J, Buchan PM, Coote JH (2001) Tracing functionally identified neurones in a multisynaptic pathway in the hamster and rat using herpes simplex virus expressing green fluorescent protein. Exp Physiol 86:695-702.

Renaud LP, Bourque CW (1991) Neurophysiology and neuropharmacology of hypothalamic magnocellular neurons secreting vasopressin and oxytocin. Prog Neurobiol 36:131-169.

Roberts MM, Robinson AG, Fitzsimmons MD, Grant F, Lee WS, Hoffman GE (1993) C-fos expression in vasopressin and oxytocin neurons reveals functional heterogeneity within magnocellular neurons. Neuroendocrinology 57:388-400.

Schadt JC, Ludbrook J (1991) Hemodynamic and neurohumoral responses to acute hypovolemia in conscious mammals. Am J Physiol 260:H305-H318.

Scislo TJ, O'Leary DS (2006) Adenosine receptors located in the NTS contribute to renal sympathoinhibition during hypotensive phase of severe hemorrhage in anesthetized rats. Am J Physiol Heart Circ Physiol 291:H2453-H2461.

Scislo TJ, Tan N, O'Leary DS (2005) Differential role of nitric oxide in regional sympathetic responses to stimulation of NTS A2a adenosine receptors. Am J Physiol Heart Circ Physiol 288: H638-H649.

Scopinho AA, Tavares RF, Busnardo C, Correa FM (2008) Non-Nmethyl-D-aspartate glutamate receptors in the paraventricular nucleus of hypothalamus mediate the pressor response evoked by noradrenaline microinjected into the lateral septal area in rats. J Neurosci Res 86:3203-3211.

Shafton AD, Ryan A, Badoer E (1998) Neurons in the hypothalamic paraventricular nucleus send collaterals to the spinal cord and to the rostral ventrolateral medulla in the rat. Brain Res 801:239-243.

Share L (1988) Role of vasopressin in cardiovascular regulation. Physiol Rev 68:1248-1284.

Shoji M, Kimura T, Kawarabayasi Y, Ota K, Inoue M, Yamamoto T, Sato K, Ohta M, Funyu T, et al. (1993) Effects of acute hypotensive hemorrhage on arginine vasopressin gene transcription in the rat brain. Neuroendocrinology 58:630-636.

Siqueira BG, Schmidt A (2003) Choque circulatório: definição, diagnóstico e tratamento. Medicina, Ribeirão Preto 36:145-150.

Starc TJ, Stalcup SA (1987) Time course of changes of plasma renin activity and catecholamines during hemorrhage in conscious sheep. Circ Shock 21:129-140.

Suzuki S, Takeshita A, Imaizumi T, Hirooka Y, Yoshida M, Ando S, Nakamura M (1989) Central nervous system mechanisms involved in inhibition of renal sympathetic nerve activity induced by arginine vasopressin. Circ Res 65:1390-1399.

Swanson LW, Kuypers HG (1980) The paraventricular nucleus of the hypothalamus: cytoarchitectonic subdivisions and organization of projections to the pituitary, dorsal vagal complex, and spinal cord as demonstrated by retrograde fluorescence double-labeling methods. J Comp Neurol 194:555-570.

Thrasher TN, Shifflett C (2001) Effect of carotid or aortic baroreceptor denervation on arterial pressure during hemorrhage in conscious dogs. Am J Physiol Regul Integr Comp Physiol 280: R1642-R1649.

Troy BP, Heslop DJ, Bandler R, Keay KA (2003) Haemodynamic response to haemorrhage: distinct contributions of midbrain and forebrain structures. Auton Neurosci 108:1-11.

Vagg DJ, Bandler R, Keay KA (2008) Hypovolemic shock: critical involvement of a projection from the ventrolateral periaqueductal gray to the caudal midline medulla. Neuroscience 152:1099-1109.

van den Pol AN, Wuarin JP, Dudek FE (1990) Glutamate, the dominant excitatory transmitter in neuroendocrine regulation. Science 250:1276-1278.

Victor RG, Thoren P, Morgan DA, Mark AL (1989) Differential control of adrenal and renal sympathetic nerve activity during hemorrhagic hypotension in rats. Circ Res 64:686-694.

Wuarin JP, Dudek FE (1991) Excitatory amino acid antagonists inhibit synaptic responses in the guinea pig hypothalamic paraventricular nucleus. J Neurophysiol 65:946-951.

Yang SJ, Hwang JC (2007) Ca + + influx is essential for the hypotensive response to arginine vasopressin-induced neuron activation of the area postrema in the rat. Brain Res 1163:56-71.

Zerbe RL, Bayorh MA, Feuerstein G (1982) Vasopressin: an essential pressor factor for blood pressure recovery following hemorrhage. Peptides 3:509-514.

Zhang K, Patel KP (1998) Effect of nitric oxide within the paraventricular nucleus on renal sympathetic nerve discharge: role of GABA. Am J Physiol 275:R728-R734. 